\title{
EFFECT OF FEEDING GRADED LEVELS OF DRIED ACACIA SALIGNA LEAVES DURING LATE PREGNANCY ON EWES PERFORMANCE AND LAMBS BIRTH WEIGHT
}

\author{
B.R. Younan ${ }^{1}$; H.M. Khattab ${ }^{2}$; Safinaz M. Shawket ${ }^{1}$; A. M. Abdel-Wahed ${ }^{1}$; A. M. \\ Mansour $^{2}$ \\ ${ }^{1}$ Animal Nutrition Department, Desert Research Centre, Egypt \\ ${ }^{2}$ Animal Production Department, Agric. Faculty, Ain Shams Univ., Egypt
}

(Received 31/12/2017, accepted 14/2/2018)

\section{SUMMARY}

$\mathrm{T}$

The study was conducted to evaluate the effect of feeding graded levels of dried Acacia saligna leaves (ALH) on the performance and some blood parameters of pregnant Barki ewes during late pregnancy. Forty ewes aged 3-5 years old at the last third of pregnancy (ten in each group, $38.0 \pm 1.2 \mathrm{~kg}$ body weight) were fed $0,20,40$ and $60 \%$ of ALH as replacement of berseem hay in a completely randomize design for 75 days. The results showed non-significant differences in daily DM intake and digestibility coefficients of DM, EE, NFE and cellulose. Diets of $40 \%$ and $60 \%$ ALH showed higher $(\mathrm{P}<0.05)$ OM, CF digestibility comparing to $20 \%$ ALH and control diets. Diets of $20 \%, 40 \%$ and $60 \%$ ALH showed higher $(\mathrm{P}<0.05)$ of $\mathrm{CP}$ digestibility comparing to control diet. The highest $(\mathrm{P}<0.05)$ nitrogen balance was recorded for ewes fed $60 \%$ followed by $40 \%$ ALH. The incorporation of ALH at levels 20, 40 and $60 \%$ resulted in non-significant differences in live body weight at all periods of the late pregnancy. Pregnant ewes fed 60\% ALH diet recorded the highest $(\mathrm{P}<0.05)$ total body weight gain $(\mathrm{Kg})$ and daily gain $(\mathrm{g} /$ day $)$ and the lowest $(\mathrm{P}<0.05)$ weight loss at lambing. Birth weight of lambs were not significantly affected. Blood urea concentrations were decreased $(\mathrm{P}<0.05)$ with the graded percentage of ALH inclusion. The results of this study revealed that inclusion of dried Acacia saligna leaves up to $60 \%$ replacement of dietary berseem hay was better for improving nutrient utilization and ewe's performance during late pregnancy stage.

Keywords: pregnant ewes, feed intake, digestibility, nitrogen utilization, body weight change, birth weight, blood parameters.

\section{INTRODUCTION}

Increasing populations, economic growth and urbanization lead to increasing demands for livestock products, which in turn are driving demand for increasing feed, and generating additional pressure on natural grazing resources. In addition, lack of regulatory mechanisms to control grazing combined with the expansion of cultivation into previously uncultivated areas is aggravating degradation of rangelands worldwide. It has been proposed that fodder shrubs and trees can be integrated into production systems to provide additional feed resources for livestock, to provide a source of fuel, to reduce wind erosion when planted as wind breaks and to stabilize or rehabilitate degraded areas, so, these plants have a potential to prevent desertification and mitigating the effects of droughts (Amira et al., 2014). Under African conditions, Acacia saligna and Acacia nilotica, leguminous trees are present in sufficient quantities to contribute to ruminant diets (Mlambo et al., 2008). Their foliage may be used as a protein and energy supplement when animals are given low quality roughage (Krebs et al, 2007). Tamira and Asefab (2009) 
reported that Acacia saligna grows on different soils but does best on light to medium loam and well drained soils. The digestibility of dry matter (DM), organic matter (OM) and energy contents of fresh $A$. saligna has been reported to be generally low mainly due to presence of anti-nutritional factors (Mahipala et al., 2009), such as tannins whose contents range from 47 to $55 \mathrm{~g} / \mathrm{kg} \mathrm{DM}$ (Ben Salem et al., 1998). Condensed tannins in A. saligna leaves are considered to be the primary anti-nutritional factors other than the fibre quality that affect its utilization as fodder by livestock (Aganga et al., 1998; Ben Salem et al., 1998). Kaitho et al. (1996) noted that drying of fodder trees species (like Acacia species) caused a reduction in tannin content of Acacia, leading to improvement in palatability and $\mathrm{N}$ utilization in the rumen (Ahn et al., 1989). For instances, Ben Salem et al. (1998) reported an increased DMI of sheep when A. saligna foliage was sun-dried, but did not show significant effect on digestibility or ruminal fermentation as compared to fresh foliage.

The crude protein and mineral contents of Acacia foliage are high enough to use it as a supplement to low quality diets (Abdulrazak et al., 2000). Many authors reported that acacia tannins can use as natural products instead of chemical treatment to protect food proteins from microbial degradation in the rumen and increase the retention of nitrogen without negative repercussion (Maamouri et al., 2011). Tannins are tentatively classified into two classes: hydrolysable and condensed tannins (CT), and are considered to have both adverse and beneficial effects depending on their concentration and nature besides other factors such as animal species, physiological state of the animal and composition of the diet (Makkar, 2003 and Frutos et al., 2004). Low concentrations of CT (20-45 g CT/kg DM) reduce rumen forage protein degradation due to reversible binding to these proteins and to reducing the populations of proteolytic rumen bacteria. The present study was carried out to investigate the effect of feeding graded level of dried Acacia Saligna leaves (ALH) on ewe's performance during late pregnancy.

\section{MATERIALS AND METHODS}

The present study was conducted in Marryot Research Station, Desert Research Center, Ministry of Agriculture, $35 \mathrm{Km}$ south of Alexandria, Egypt during 2014-2015.

\section{Acacia saligna hay preparation}

Enough amounts of the fresh Acacia leaves were collected from the farm of Marryot station and Borg El-Arab Road and chopped to 3-5 cm length. After chopping, Acacia leaves were dried at shaded area for 3-4 days by spreading on plastic sheets, (air-drying). Samples of hay were taken for subsequent proximate chemical analyses.

\section{Feeding and management}

Forty of Barki ewes at the last third of pregnancy aged 3-5 years old with an average live body weight $38.0 \pm 1.2 \mathrm{~kg}$ were randomly allocated to four treatments groups (ten ewes per group); each group was housed separately in shaded $5 \times 5$ meter pens and fed their normal allowances according to the experimental assignment during the pregnancy. Feeds were offered twice daily at 9:00 AM and 5:00 PM. Fresh tap water was made available for free choice drinking once daily after the morning feeding. Refusals were collected in the following morning, weighed and sampled, and daily intake was recorded. Pregnant ewe's body weights were recorded.

Blood samples were withdrawn from jugular vein of all ewes at morning before offering feed and water at the last day of experiment. The experimental animals were kept under the same managerial and hygienic condition. Before starting the experiment animals were treated against internal and external parasites and intro-toxemia.

The requirements of digestible $\mathrm{CP}$ and metabolizable energy (ME) for ewes at the last period of pregnancy were calculated according to the recommended feeding standards of Kearl (1982). The experimental diets were prepared to replace berseem hay by $0 \%$ (Control), $20 \%$ (20\% ALH), $40 \%$ ( $40 \%$ 
ALH) and 60\% (60\% ALH) Acacia saligna leaves hay. The compositions and chemical analysis of the experimental diets are presented in Tables (1) and (2).

Table (1). Formulation of ewe's experimental diets (\%, on DM basis).

\begin{tabular}{lcccc}
\hline \multirow{2}{*}{ Ingredient } & \multicolumn{4}{c}{ Experimental Diet } \\
\cline { 2 - 4 } & Control & $20 \%$ ALH & $40 \%$ ALH & $60 \%$ ALH \\
\hline CFM $^{*}$ & 36.0 & 36.0 & 36.0 & 36.0 \\
Yellow corn & 24.0 & 24.0 & 24.0 & 24.0 \\
Berseem hay & 40.0 & 32.0 & 24.0 & 16.0 \\
\hline Acacia saligna leaves & 0.0 & 8.0 & 16.0 & 24.0 \\
\hline
\end{tabular}

"CFM: commercial concentrate feed mixture.

\section{Digestibility trials}

Five ewes chosen randomly for each digestibility trial at weaning. The digestibility trials lasted for three weeks, the first two weeks were considered as preliminary period, followed by 7 days as collection period. Animals were housed in individual metabolic cages. During the trials the animals were fed their normal allowances according to the experimental assignment. Faeces and urine were quantitatively collected from each animal. The daily faeces excreted of each animal were recorded and $10 \%$ was subsampled, pooled on animal basis and frozen pending chemical analysis. The urine was collected in plastic buckets containing a solution of $100 \mathrm{ml}$ of $10 \% \mathrm{H}_{2} \mathrm{SO}_{4}$ to prevent ammonia-N loss. The daily output from each animal was weighed and $10 \%$ sub-sampled, pooled on animal basis and stored at $4{ }^{\circ} \mathrm{C}$ until the analysis of nitrogen. Feed residues were removed daily at $7 \mathrm{AM}$ and weighed. Daily drinking water volume was recorded. Proximate analysis of feeds, faeces, urine for ash, ether extract, crude protein, crude fiber and fiber fraction were determined according to the procedure of A.O.A.C. (1995).

\section{Statistical analysis}

Data were statistically analyzed using the method of least squares analysis of variance using software SPSS 10.0 windows (SPSS, 1999), using the following model; $Y_{i j}=\mu+T_{i}+e_{i j}$, Where; $Y_{i j}$ is the observation, $\mu$ is the overall mean, $T_{i}$ is the effect of treatments and $e_{i j}$ is the residual error. Differences in mean values between groups were compared by Duncan's Multiple Range Test (Duncan, 1955).

\section{RESULTS AND DISCUSSION}

\section{Chemical composition of feed ingredients}

The chemical composition of feed ingredients is presented in Table (2). Dry matter (DM), crude protein $(\mathrm{CP})$, crude fibre $(\mathrm{CF})$, ether extract (EE) and fiber fraction contents of Acacia saligna hay were comparable to those of berseem hay. Whereas, Acacia hay had higher values of NFE and lower value of ash than berseem hay. Also, acid detergent lignin (ADL) and hemicellulose contents of Acacia hay were higher than those of berseem hay while cellulose was noticably lower. The present results of chemical composition of berseem hay are comparable to the values reported by Shawket and Ahmed, (2001) and Shawket et al. (2010). The present chemical analysis (\%) of Acacia hay was little more or less agreement with the values reported by Abou El Nasr et al. (1996) who indicated, DM: 86.4 and 89.53; CP: 10.1 and 17.63; CF: 28.1 and 22 81; EE: 4.40 and 1.16; NFE: 44.1 and 44.73; ash: 13.3 and 13.67; NDF: 69.5 43.90; ADF: 44.7 and 23.83 and ADL: 16.8, respectively, for Acacia hay. These wide variations of Acacia hay chemical composition may be due to differences in environmental and climatic conditions, the 
vegetation period of plant, the processing method of drying under shade or in the sun, handling and storage conditions.

Table (2): Chemical composition of the experimental feedstuffs (on DM basis)

\begin{tabular}{lcccc}
\hline Items & Brseem hay & Acacia hay & CFM & Crushed corn grains \\
\hline DM & 91.5 & 92.6 & 91.5 & 89.7 \\
CP & 12.9 & 11.5 & 12.9 & 8.0 \\
CF & 27.9 & 26.6 & 15.8 & 1.6 \\
EE & 2.6 & 3.0 & 3.0 & 5.3 \\
NFE & 44.0 & 51.7 & 54.3 & 83.0 \\
Ash & 12.6 & 7.2 & 14.0 & 2.1 \\
NDF & 55.0 & 58.7 & 50.6 & 50.5 \\
ADF & 47.2 & 49.9 & 29.9 & 7.0 \\
ADL & 8.7 & 21.0 & 12.0 & 0.0 \\
Hemicellulose & 8.3 & 8.8 & 20.7 & 43.5 \\
Cellulose & 38.5 & 28.9 & 17.9 & 7.0 \\
\hline
\end{tabular}

CFM: commercial concentrate feed mixture, DM: dry matter; OM: organic matter; CP: crude protein; CF: crude fiber; EE: ether extract; NFE: nitrogen free extract; NDF: neutral detergent fibre; ADF: acid detergent fiber and $A D L:$ acid detergent lignin.

Table (3). Chemical analysis of the experimental diets (\%, on DM basis).

\begin{tabular}{|c|c|c|c|c|}
\hline \multirow{2}{*}{ Item } & \multicolumn{4}{|c|}{ Experimental Diets } \\
\hline & Control & $20 \% \mathrm{ALH}$ & $40 \% \mathrm{ALH}$ & $60 \% \mathrm{ALH}$ \\
\hline DM & 91.49 & 91.15 & 91.24 & 91.33 \\
\hline OM & 86.59 & 96.74 & 90.17 & 90.60 \\
\hline $\mathrm{CP}$ & 12.90 & 12.64 & 11.50 & 11.39 \\
\hline $\mathrm{CF}$ & 20.67 & 19.38 & 17.05 & 16.94 \\
\hline EE & 2.84 & 3.63 & 3.46 & 3.49 \\
\hline NFE & 50.18 & 61.08 & 58.16 & 58.79 \\
\hline Ash & 13.41 & 11.26 & 9.83 & 9.40 \\
\hline NDF & 52.53 & 57.21 & 53.03 & 53.29 \\
\hline $\mathrm{ADF}$ & 36.82 & 35.31 & 31.75 & 31.97 \\
\hline ADL & 10.67 & 9.47 & 9.76 & 10.74 \\
\hline Hemi-cellulose & 15.71 & 21.90 & 21.28 & 21.32 \\
\hline Cellulose & 26.15 & 25.84 & 21.99 & 21.23 \\
\hline
\end{tabular}

\section{Digestibility coefficient and nutritive value}

The digestibility of the experimental diets is presented in Table (4) indicating non-significant effect of Acacia levels on the digestibility coefficients for DM, OM, EE, NFE and cellulose. While, $40 \%$ and $60 \%$ ALH diets showed the higher $(\mathrm{P}<0.05)$ OM digestibility coeffecient compared to $20 \%$ ALH and control diets (69.60 and 69.40 vs. 66.90 and 65.80\%, respectively). Also, 20, 40 and 60\% ALH diets recorded higher $(\mathrm{p}<0.05) \mathrm{CP}$ digestibility comompared to control diet $(72.69,73.78$ and 73.01 vs. $70.11 \%$, respectively). Inclusion 40 and $60 \% \mathrm{ALH}$ in ewes diets showed higher $(\mathrm{P}<0.05) \mathrm{CF}$ digestibility compared to $20 \% \mathrm{ALH}$ and control diets (68.60 and 70.70 vs. 65.80 and $66.50 \%$, respectively). At the same trend, 20, 40 and 60\% ALH diets recorded higher $(\mathrm{P}<0.05)$ digestibility coefficients of NDF than control diet $(55.5,56.0,55.0$ vs. 51.1\%, respectively), also $60 \%$ ALH diet recorded the highest $(\mathrm{P}<0.05)$ ADF digestibility (56.2) compared to control, 20 and 40\% ALH diets (53.4, 52.2 and 53.0 \%, respectively), similarly, hemicellulose digestibility coefficient showed almost similar values $(76.5,74.8$, 73.6 and $70.8 \%$ for $60,20,40 \%$ ALH and control diets, respectively). 
Table (4): Effect of degraded levels of ALH inclusion instead berseem hay in the experimental diets on nutrients digestibility and nutritive value

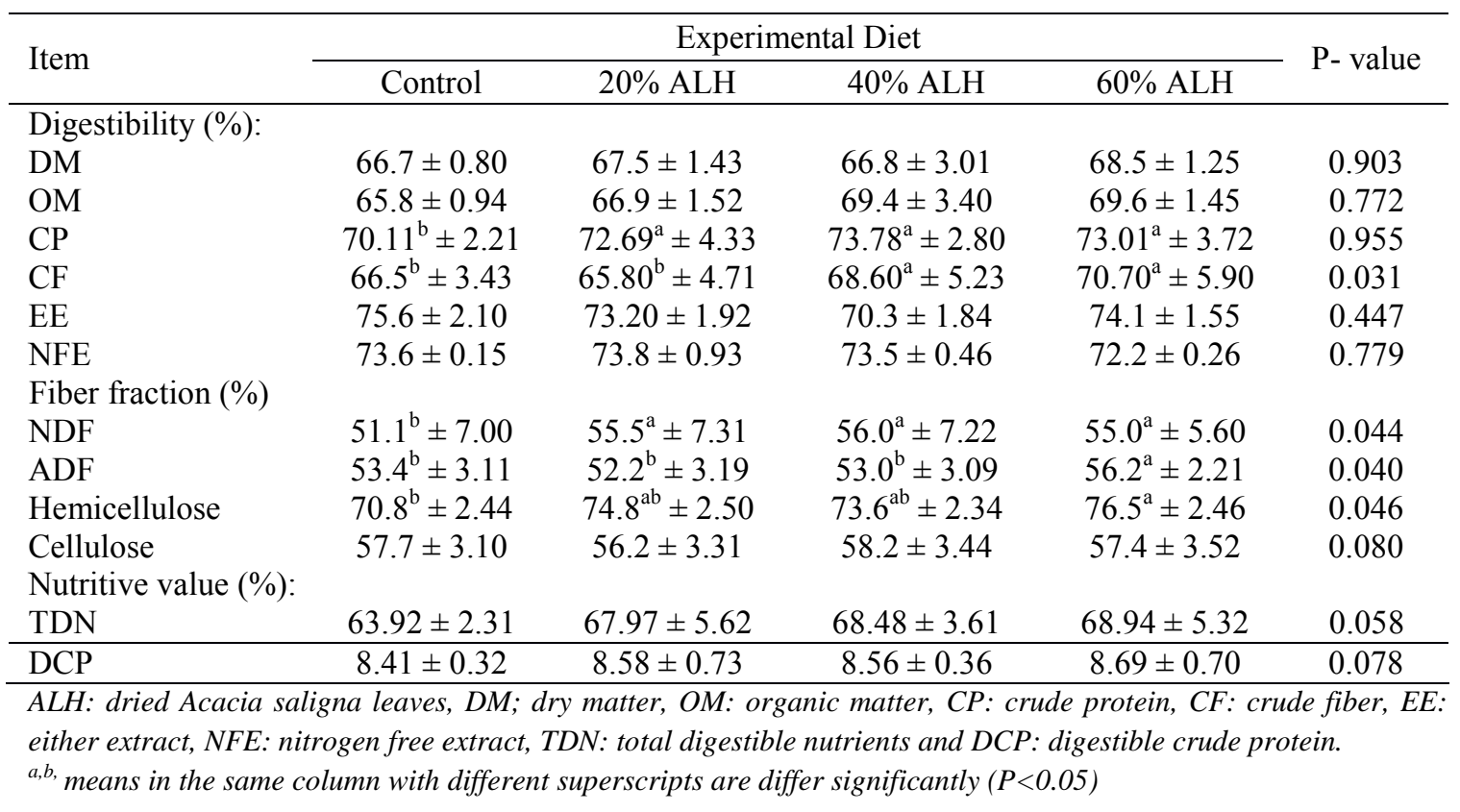

The present result of increasing $(\mathrm{P}<0.05)$ NDF digestibility with the inclusion of dried Acacia saligna leaves (ALH) instead of berseem hay is in agreement with those reported by Maamouri et al. (2011) who found that Acacia cyanophylla (Acacia saligna) supply leads to a significant $(\mathrm{P}<0.05)$ increase in NDF digestibility. Tannins mainly exert their effect on proteins, but they also affect other feed components to different degrees (Kumar and singh, 1984). Evidently, the modifications of digestibility caused by tannins ingestion are mainly associated with changes in the rumminal fermentation pattern, along with changes in intestinal digestibility. O'Donovan and Brooker (2001) indicated that ruminal bacteria with proteolytic and firolytic activity can be adapted after a short time to tannins administration at low levels $(<50 \mathrm{~g} / \mathrm{Kg}$ DM) and successively continue their function. This may be explaining the improve digestibility of fiber fractions with inclusion ALH instead of berseem hay.

Total digestible nutrients (TDN, \%) and digestible crude protein (DCP, \%) values of the experimental diets showed no significant difference $(\mathrm{P}>0.05)$ due to the graded percentage levels of replacing ALH instead berseem hay. Close to the present results of, El-Lakany et al. (1991) reported that replacing 50\% of the daily DM alfalfa intake for Barki sheep with Acacia foliage slightly increased total digestible nutrients (TDN). The positive present results of DCP\% values may be due to drying causing a reduction in tannin content of Acacia species foliage by about 11.3\% (Van Thanh et al., 2005), thus improving $\mathrm{N}$ utilization in the rumen (Ahn et al., 1989 and Tamira and Asefab, 2009).

\section{Nitrogen utilization}

The nitrogen utilization results are presented in Table (5). The highest nitrogen intake was recorded for Barki ewes fed control followed by $60 \%$ ALH. The lowest $(\mathrm{P}>0.05)$ nitrogen intake was recorded for $20 \%$ ALH diet $(24.2 \mathrm{~g} / \mathrm{h} / \mathrm{d})$. Dietary treatments did not affect significantly $(\mathrm{P}>0.05)$ nitrogen excretion in faeces. But inclusion of ALH at levels of 60 and $40 \%$ instead of berseem hay decreased $(\mathrm{P}<0.05)$ urinary nitrogen $(10.2$ and $10.9 \mathrm{~g} / \mathrm{h} / \mathrm{d}$, respectively). While higher $(\mathrm{P}<0.05)$ nitrogen excretions in urine were recorded for ewes fed control and 20\% ALH diets (13.5 and $13.1 \mathrm{~g} / \mathrm{h} / \mathrm{d}$, respectively). This result is in agreement with the previous finding of Maamouri et al. (2011) that simultaneous Acacia supply decreased $(\mathrm{P}<0.05)$ urinary $\mathrm{N}$. They reported that animals receiving protein $\mathrm{N}$ and a small quantity of tannins lost $(\mathrm{P}<0.01)$ less $\mathrm{N}$ proportion in urine. Also, it was found that reduced urinary $\mathrm{N}$ is consistent with a reduction in rumminal ammonia losses, due to protein protection by condensed tannins (Krebs et al., 2007). Diets containing 60 and $40 \%$ ALH had higher $(\mathrm{P}<0.05)$ nitrogen absorption, while control and 
20\% ALH diets had less nitrogen absorption (16.4 and 14.2 vs. 13.4 and $11.1 \mathrm{~g} / \mathrm{h} / \mathrm{d}$, respectively). The urinary $\mathrm{N}$ as a proportion of total $\mathrm{N}$ excretion $(\%)$ was lower $(\mathrm{P}<0.05)$ with feeding 40 and $60 \%$ ALH diets than $20 \%$ and control diets resulting in a shift of relative $\mathrm{N}$ excretion from urine (47.66 and 52.15 vs. 56.47 and $56.25 \%$, respectively) to faeces (52.34, 47.85 and 43.53 and 43.75 , respectively).

Table (5): Nitrogen utilization (g/head/day) by dry Barki ewes fed the experimental diets.

\begin{tabular}{|c|c|c|c|c|c|}
\hline \multirow{2}{*}{ Item } & \multicolumn{4}{|c|}{ Experimental Diet } & \multirow{2}{*}{ P- Value } \\
\hline & Control & $20 \% \mathrm{ALH}$ & $40 \% \mathrm{ALH}$ & $60 \% \mathrm{ALH}$ & \\
\hline No. of animals & 5 & 5 & 5 & 5 & ----- \\
\hline $\begin{array}{l}\text { Nitrogen intake, } \\
\mathrm{g} / \mathrm{h} / \mathrm{d}\end{array}$ & $27.00 \pm 0.57$ & $24.20 \pm 1.99$ & $25.10 \pm 1.29$ & $26.60 \pm 0.78$ & 0.605 \\
\hline $\begin{array}{l}\text { Faecal nitrogen, } \\
\mathrm{g} / \mathrm{h} / \mathrm{d}\end{array}$ & $8.07 \pm 0.58$ & $6.61 \pm 1.13$ & $6.58 \pm 0.76$ & $7.18 \pm 1.33$ & 0.913 \\
\hline $\begin{array}{l}\text { Urinary nitrogen, } \\
\mathrm{g} / \mathrm{h} / \mathrm{d}\end{array}$ & $15.22^{\mathrm{a}} \pm 1.24$ & $12.88^{b} \pm 0.74$ & $12.01^{\mathrm{b}} \pm 1.18$ & $11.12^{c} \pm 0.91$ & 0.040 \\
\hline FN $\%$ of TNE & $43.65 \pm 0.34$ & $33.91 \pm 0.61$ & $37.41 \pm 0.55$ & $39.23 \pm 0.63$ & 0.042 \\
\hline UN $\%$ of TNE & $65.35 \pm 0.59$ & $66.09 \pm 0.64$ & $68.22 \pm 0.48$ & $60.77 \pm 0.72$ & 0.047 \\
\hline $\mathrm{NB}, \mathrm{g} / \mathrm{h} / \mathrm{d}$ & $3.71^{c} \pm 0.99$ & $4.71^{\mathrm{c}} \pm 0.35$ & $7.51^{b} \pm 1.72$ & $8.30^{\mathrm{a}} \pm 1.35$ & 0.038 \\
\hline NB $\%$ of $\mathrm{NI}$ & $13.74^{\mathrm{a}} \pm 3.73$ & $19.46^{\mathrm{c}} \pm 1.34$ & $29.92^{c} \pm 6.61$ & $31.20^{\mathrm{c}} \pm 5.05$ & 0.009 \\
\hline $\mathrm{NB} \%$ of $\mathrm{NA}$ & $19.60^{c} \pm 3.73$ & $26.78^{\mathrm{c}} \pm 1.34$ & $40.55^{\mathrm{b}} \pm 6.61$ & $42.74^{\mathrm{a}} \pm 5.05$ & 0.005 \\
\hline
\end{tabular}

In general, all diets showed positive nitrogen balance $(\mathrm{NB})$. The highest $(\mathrm{P}<0.05)$ nitrogen balance was recorded for ewes fed 60\% ALH diet followed by those fed 40\% ALH (7.51\%) and 20\% ALH (4.71\%). however, the lowest NB was recorded for the control (3.71). The present values of NB are closer to those reported by Maamouri et al. (2011) and ranged from 2.6 to $10.6 \mathrm{~g} /$ day. They indicated that concentrate and increasing Acacia level supply resulted in the highest $(\mathrm{P}<0.01)$ nitrogen retention. Moreover, the present results are in agreement with those reported by Barry et al. (1986) and Monteils et al. (2003).

Nitrogen balance (NB) reported as a percent of $\mathrm{N}$ intake had the same tendency as quantity NB. Barki ewes fed 60 and 40\% ALH diets showed the highest $(\mathrm{P}<0.01)$ value of NB \% NI $(31.20$ and 29.92\%, respectively), while $20 \% \mathrm{ALH}$ and control diets showed the lowest $(\mathrm{P}<0.01)$ values $(4.71$ and $3.71 \%$, respectively). At the same line, highest $(\mathrm{P}<0.01) \mathrm{NB} \%$ of NA values $(42.74$ and $40.55 \%$, respectively) were recorded for ewes fed 60 and 40\% ALH diets while the lowest values (26.78 and 19.60\%, respectively) were recorded for those fed $20 \%$ ALH and control diets. These results are in agreement with those reported by Maamouri et al. (2011), they suggested that tannins supply interacted with the dietary protein and reduced its rumen microbial protein degradation, therefore they played the role of protein protection. Also, the condensed tannins bind protein and other macromolecules in the rumen, may reduce availability of the nutrients to microorganism degradation (McAllister et al., 2005).

The advantage in this process is that excessive ammonia production in the rumen could be reduced, decreasing urinary $\mathrm{N}$ losses. As a result, nitrogen retention may increase in ruminants fed tannins-rich plants (Kaitho et al., 1996) or remain without effect (Carulla et al., 2005 and Bengaly et al., 2007). Also, Reed (1995) reported that tannin-protein complex allows more dietary protein to escape rumen degradation to reach the lower digestive tract and allows a better flow of amino acids which had a positive effect on sheep performance grazing on semi-arid ranges (Maamouri et al., 2011).

\section{Last third period of pregnancy}

\section{Feed intake}

Results of Table (6) indicated that the inclusion of $20 \%$ ALH instead of BH slightly decreased $(\mathrm{P}>0.05)$ the total DM intake $\left(\mathrm{g} / \mathrm{h} /\right.$ day or $\left.\mathrm{g} / \mathrm{kg} \mathrm{w}^{0.75}\right)$. While increasing the inclusion level of ALH to 40 
and $60 \%$ instead of $\mathrm{BH}$ showed a slight increase $(\mathrm{P}>0.05)$ in daily DM intake $(1303.8 \mathrm{~g} / \mathrm{h} / \mathrm{day}, 76.60$ $\mathrm{g} / \mathrm{Kgw}^{0.75}$ and $1288.4 \mathrm{~g} / \mathrm{h} / \mathrm{day}, 76.98 \mathrm{~g} / \mathrm{kg} \mathrm{w}^{0.75}$, respectively) in comparison with the control and $20 \%$

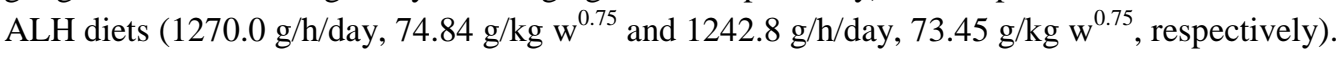

When feed intake values were expressed as total digestible nutrient intake (TDNI) it was noticeable that $40 \%$ ALH diet recorded the highest values $\left(910.1 \mathrm{~g} / \mathrm{h} / \mathrm{day}, 53.54 \mathrm{~g} / \mathrm{kg} \mathrm{w}^{0.75}\right)$, followed by $60 \%$ ALH

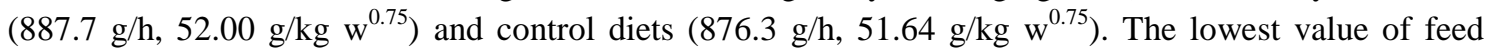
intake was recorded for $20 \%$ ALH diet (847.7 and 50.09). However, when the DCP values were expressed as $\mathrm{g} / \mathrm{kg} \mathrm{w}^{0.75}$, the control and $60 \%$ ALH diets recorded the highest values (6.88 and 6.91, respectively) followed by values of 20 and $40 \%$ ALH diets (6.68 and 6.98, respectively) At the same trend, pregnant ewes fed 40\% ALH recorded the highest value of DCP intake whereas those fed $20 \%$ ALH showed the lowest one (118.6, 116.8 and 116.0 vs. 113.1 for $40 \%$ ALH, control, 60\% ALH and $20 \%$ ALH diets, respectively). However, there were no significant differences for TDN and DCP intake due to changing the level of ALH supplementation.

The present results of DM intake are in a good agreement with those obtained by Meneses, et al. (2012). They studied the effect of using Acacia saligna (Labill.) H.L. forage as an alternative feed supply for goats during the late pregnancy instead of alfalfa (Medicago sativa L.) hay 0, 25, 50, 75 and $100 \%$. They found that the level of $25 \%$ of Acacia hay replacement instead of alfalfa hay slightly decreased the DM intake compared to the values of DM intake of control group. When the level of Acacia supplementation was increased to $50 \%$ instead of alfalfa hay the DM intake increased by about $1.6 \%$ than that of control group however the DM intake decreased $(\mathrm{P}<001)$ in diet with $70 \%$ and $100 \%$ Acacia. Moujahed et al., (2005) reported that increasing the level of Acacia leaves in the animal diets decreased the DMI which may be attributed to the un-palatability of the diet as a result of increasing tannins content. Also, the reduction in dry matter intake may be due to the lower intestinal motility which led to a higher retention time of the digest in the gut (Garcia, et al., 1999).

Table (6): Feed intake of the experimental diets supplemented with different levels of Acacia leaves hay (ALH) fed to Barki ewes at late pregnancy stage

\begin{tabular}{|c|c|c|c|c|}
\hline \multirow{2}{*}{ Item } & \multicolumn{4}{|c|}{ Experimental Diets } \\
\hline & Control & $20 \%$ ALH & $40 \% \mathrm{ALH}$ & $60 \%$ ALH \\
\hline No. animals & 10 & 10 & 10 & 10 \\
\hline Initial B. Wt. (Kg) & $39.8 \pm 4.49$ & $38.9 \pm 1.77$ & $39.9 \pm 3.15$ & $38.3 \pm 1.36$ \\
\hline Final B. Wt. (Kg) & $47.4 \pm 5.15$ & $47.0 \pm 3.64$ & $47.5 \pm 2.46$ & $47.6 \pm 2.60$ \\
\hline $\mathrm{MBW}, \mathrm{Kg}^{0.75}$ & 16.97 & 16.92 & 17.00 & 16.78 \\
\hline \multicolumn{5}{|l|}{ Con. DMI, g/h/day } \\
\hline CFM & 600.0 & 587.2 & 615.9 & 608.7 \\
\hline Yellow Corn & 160.0 & 156.6 & 164.3 & 162.3 \\
\hline \multicolumn{5}{|l|}{ Roug. DMI, g/h/day } \\
\hline $\mathrm{BH}$ & 510.0 & 399.2 & 314.1 & 207.0 \\
\hline $\mathrm{ALH}$ & ---- & 99.8 & 209.5 & 310.4 \\
\hline \multicolumn{5}{|l|}{ Total DMI } \\
\hline $\mathrm{g} / \mathrm{h} /$ day & $1270 \pm 14.51$ & $1242.8 \pm 18.05$ & $1303.8 \pm 12.12$ & $1288.4 \pm 13.41$ \\
\hline $\mathrm{g} / \mathrm{Kgw}^{0.75}$ & $74.84 \pm 18.02$ & $73.45 \pm 15.96$ & $76.69 \pm 13.68$ & $76.98 \pm 18.55$ \\
\hline \multicolumn{5}{|l|}{ TDNI } \\
\hline g/ h/day & $876.3^{\mathrm{c}} \pm 14.74$ & $847.6^{\mathrm{b}} \pm 7.64$ & $910.1^{\mathrm{b}} \pm 10.32$ & $887.7^{\mathrm{a}} \pm 4.47$ \\
\hline $\mathrm{g} / \mathrm{kg} \mathrm{w}^{0.75}$ & $51.64 \pm 10.11$ & $50.09 \pm 10.91$ & $53.54 \pm 9.88$ & $52.90 \pm 11.02$ \\
\hline \multicolumn{5}{|l|}{ DCPI } \\
\hline${\mathrm{g} / \mathrm{kg} \mathrm{w}^{0.75}}^{0.71}$ & $6.88 \pm 6.31$ & $6.68 \pm 5.98$ & $6.98 \pm 6.11$ & $6.91 \pm 5.78$ \\
\hline
\end{tabular}

While Ben Salem et al. (1997) reported that increasing the level of air-dried Acacia saligna foliage in the Lucerne basal diet increased DM intake $(\mathrm{P}<0.01)$ by sheep up to approximately $600 \mathrm{~g} \mathrm{DM}$ head/day of Acacia. This value (600 DM g /h/day) of voluntary intake of Acacia was noticeably greater than $170 \mathrm{~g}$ 
DM Acacia/day and 165 g DM Acacia/day that were measured by Reed et al. (1990) and Ben Salem and Nefzaoui (1993), respectively in sheep fed straw-based diets. They indicated that feeding sheep with good quality roughage (i.e. Lucerne hay) improve Acacia consumption. It may be hypothesized that a component of the Lucerne, possibly protein, interacted with Acacia tannins in the rumen and reduced their effects on rumen function and thus voluntary intake. This explanation may confirm the current results of increasing DM intake with increasing the inclusion level of dried Acacia hay to 40 and $60 \%$ instead of berseem hay.

\section{Pregnant ewes body weight changes, daily gain and body weight loss after lambing and lamb birth weight.}

The results of the effect of Acacia supplementation on body weight changes, daily gain and body weight loss after lambing of ewes and lamb birth weight are presented in Table (7) and Figure (1). Initial body weight of Barki pregnant ewes ranged from 38.3 to $39.9 \mathrm{~kg}$ with no significant differences among treatments, which means a random distribution of the pregnant ewes on the different treatments. The incorporation of Acacia leave hay (ALH) at level 60\% recorded the highest total live body weight gain and ADG. However, it was observed that pregnant ewes fed $40 \%$ ALH diet recorded the same total body weight gain and ADG that were recorded by those fed control, and slightly lower than those fed $40 \%$ ALH diet. The present results are in good agreement with those of Meneses, et al., (2012) who reported that when goats in late pregnancy fed alfalfa hay diet (control) and replacement Acacia hay instead of alfalfa hay by $25,50,75$ and $100 \%$ diets, the body weight changes did not show a significant differences ( $\mathrm{P} 0>0.05)$ among treatments. They illustrated that $\mathrm{CP}$ and ME intake during the experimental treatments was probably not sufficient to establish significant responses during the last third period of pregnancy.

During the late pregnancy stage, the increase in live body weight was accounted for both body gain and fetal growth, the $60 \%$ ALH fed group was superior $(\mathrm{P}<0.05)$ than the $20 \%$ ALH followed by $40 \%$ ALH and control groups (9.3 vs. 8.1, 7.6 and $7.6 \mathrm{Kg}$, respectively). These values are closer to that reported by Farid et al. (2005a) who reported that pregnant Barki ewes received NRC standards (1985), gained, 9.54 Kg for pregnant group fed ad lib berseem hay, $6.09 \mathrm{Kg}$ for ewes group fed one-third berseem hay plus ad lib rice straw and $6.63 \mathrm{Kg}$ for the group fed ad lib rice straw with added commercial molasses-urea mixture. The present results of ewes body weight gain revealed better feeding during late pregnancy seemed to improve ewe condition more than that of the offspring and production rate (Farid $e t$ al., 2005a). The difference in daily body weight gain values were significant $(\mathrm{P}<0.05)$ among the Barki ewes groups during the whole experimental period. The minimum value was recorded for both pregnant ewes groups received the control (135.7 g/h/day) and 20\% ALH (144.6 g/h/day) diets and the maximum value was recorded for pregnant ewes group received $60 \%$ ALH diet $(166.7 \mathrm{~g} / \mathrm{h} / \mathrm{d})$ and consequently had the highest $(\mathrm{P}<0.05)$ daily weight gain followed by 40\%, $20 \% \mathrm{ALH}$ and control ewe groups respectively. Live body weight recorded on the first day after lambing was optimum for the $60 \%$ ALH group being $39.5 \mathrm{Kg}$. For the other three groups, live body weights were $38.6 \mathrm{Kg}$ for the $40 \%$ ALH group and $38.4 \mathrm{Kg}$ for both $20 \%$ ALH and control groups, they had the same body weight after lambing . These present body weight s values are below the recorded values for Barki ewes fed according to NRC (1985) standards $(44.0 \mathrm{Kg})$ or $(45.8 \mathrm{Kg})$ for those fed $\mathrm{ad}$ lib berseem hay $+200 \mathrm{~g}$ concentrate /day/ewe (4 parts ground corn grain and 1 part soybean meal) as reported by Farid et al. (2005a). These differences may be due to the condition of the ewes at the start of the experiment was below optimum. The overall average live body weight was about $38 \mathrm{Kg}$ (Farid et al., 2005b). This is much less than the $45 \mathrm{~kg}$ considered optimum for Barki, one of the smaller Egyptian breeds (Abd El-Aziz, 1983, Mohammed, 1999). Loss in body weight at calving and loss percentage were significant $(\mathrm{P}<0.05)$ differ among the experimental groups. It worthy to note that $60 \%$ ALH ewes group recorded the lowest $(\mathrm{P}<0.05)$ loss value in body weight than the other three ewe groups with no significant differences between them. The values of loss percent of pre-lambing body weight were taken the same trend. Results, showed that the inclusion of ALH instead of berseem hay at levels of 20, 40 and $60 \%$ resulted in non-significant differences $(\mathrm{P}>0.05)$ in lamb's birth weight (neglecting the lambs sex). The present birth weight values are lower than the average values (males and females) 3.7 and 3.9 Kg of lambs born for Barki dams fed according to NRC standers (1985) and those fed $a d$ lib berseem hay $+200 \mathrm{~g} / \mathrm{ewe} /$ day concentrate, respectively, and higher than the average 
birth weight $3.2 \mathrm{Kg}$ of lambs born for Barki ewe dams fed ad lib rice straw with added a commercial molasses-urea mixture $+200 \mathrm{~g} / \mathrm{ewe} /$ day concentrate (Farid et al., 2005b).

Table (7): Effect of graded levels of Acacia leaf hay inclusion instead of berseem hay on body weight change (Kg) of pregnant of Barki ewes and lambs birth weight.

\begin{tabular}{lcccrc}
\hline \multirow{2}{*}{ Item } & \multicolumn{4}{c}{ Experimental Diet } & \multirow{2}{*}{ P-value } \\
\cline { 2 - 5 } & Control & $20 \%$ ALH & $40 \%$ ALH & $60 \%$ ALH & \\
\hline Initial B. Wt. $(\mathrm{Kg})$ & $39.8 \pm 4.49$ & $38.9 \pm 1.77$ & $39.9 \pm 3.15$ & $38.3 \pm 1.36$ & --- \\
Final B. Wt. $(\mathrm{Kg})$ & $47.4 \pm 5.15$ & $47.0 \pm 3.64$ & $47.5 \pm 2.46$ & $47.6 \pm 2.60$ & --- \\
Gain (Kg) & $7.6^{\mathrm{b}} \pm 3.64$ & $8.1^{\mathrm{ab}^{\mathrm{b}} \pm 5.12}$ & $7.6^{\mathrm{b}} \pm 6.81$ & $9.3^{\mathrm{a}} \pm 5.44$ & 0.042 \\
ADG g/day & $135.7^{\mathrm{b}} \pm 10.11$ & $144.6^{\mathrm{ab}} \pm 12.53$ & $135.7^{\mathrm{b}} \pm 9.87$ & $166.7^{\mathrm{a}} \pm 15.26$ & 0.033
\end{tabular}

Loss in body weight on calving

$\begin{array}{llllll}\text { B. Wt after calving }(\mathrm{Kg}) & 38.4 \pm 6.59 & 38.4 \pm 9.12 & 38.6 \pm 7.66 & 39.5 \pm 9.04 & 0.068\end{array}$

$\begin{array}{llllll}\text { Loss }(\mathrm{Kg}) & -9.0^{\mathrm{a}} \pm 0.95 & -8.6^{\mathrm{a}} \pm 0.70 & -8.9^{\mathrm{a}} \pm 0.82 & -8.1^{\mathrm{b}} \pm 0.43 & 0.025\end{array}$

$\begin{array}{llllll}\text { Loss } \% \text { of pre-calving } & 19.0^{\mathrm{a}} \pm 0.72 & 18.3^{\mathrm{a}} \pm 0.96 & 18.7^{\mathrm{a}} \pm 2.21 & 17.0^{\mathrm{b}} \pm 1.83 & 0.050 \\ \text { weight }\end{array}$

New born lambs

\begin{tabular}{|c|c|c|c|c|c|}
\hline Birth weight (Kg) & $3.5 \pm 0.21$ & $3.4 \pm 0.19$ & $3.4 \pm 0.25$ & $3.5 \pm 0.27$ & 0.088 \\
\hline
\end{tabular}

$a, b$ Means in the same raw with different superscripts are differ significantly $(P<0.05)$.

$A D G=$ final - initial body weight/45

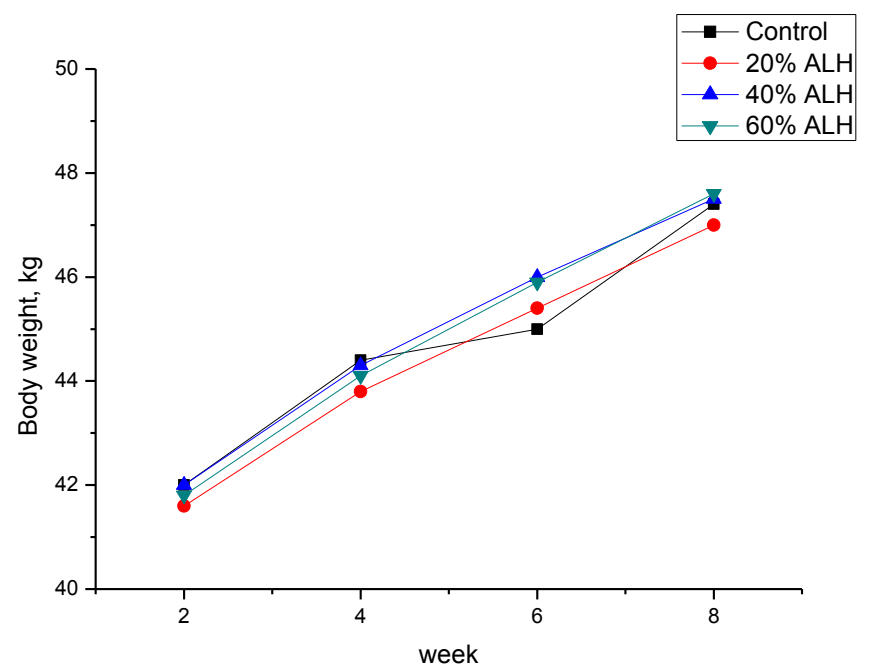

Figure (1): Body weight change of ewes fed diets supplemented with grade levels of Acacia saligna hay instead of berseem hay during late pregnancy

\section{Blood parameters}

Results of Table (8) clearly show no significant changes concerning total proteins, albumin, globulin, albumin/globulin ratio (A/G ratio) and creatinine concentration among treatments. The present values of blood metabolites except urea are within the normal range reported by Mousa and Shetaewi (2002) on 
ewes fed Acacia and higher than the blood metabolites value reported by Hassan et al. (2015) for ewes fed $300 \mathrm{~g}$ ground barley grains + ad lib Acacia saligna.

On the other hand, blood urea concentrations were decreased $(\mathrm{P}<0.05)$ with the graded percentage of ALH inclusion (42.59, 47.73, 51.67 vs. $54.68 \mathrm{mg} / \mathrm{dL}$ for ewes fed 60, 40, 20\% ALH and control diets, respectively). This result is in agreement with that reported by Carulla et al. (2005) added tannins to ewes diet decreased $(\mathrm{P}<0.01)$ blood urea $\mathrm{N}$ concentration suggesting that less protein was degraded with reducing microbial proteolytic activity in the rumen. Similar observations have been shown in vitro (Hess et al., 2004) and in vivo (Carulla et al., 2001) when tanniniferous forages supplemented. These studies have demonstrated an overall improvement of $\mathrm{N}$ utilization. Also, at the same trend Maamouri et al. (2011) and Meneses et al. (2012) indicated that blood urea and urinary $\mathrm{N}$ loss were decreased $(\mathrm{P}<0.05)$ when sheep and goats were fed legumes that contained tannins. Generally, the values obtained of blood constituents indicated normal physiological and healthy status of ewes fed the experimental diets.

Table (8): Blood parameters as affected by the graded level of dried Acacia saligna leaves inclusion instead of berseem hay.

\begin{tabular}{|c|c|c|c|c|c|}
\hline \multirow{2}{*}{ Item } & \multicolumn{4}{|c|}{ Experimental Diet } & \multirow{2}{*}{ P-value } \\
\hline & Control & $20 \%$ ALH & $40 \% \mathrm{ALH}$ & $60 \% \mathrm{ALH}$ & \\
\hline $\mathrm{TP}, \mathrm{g} / \mathrm{dL}$ & $7.74 \pm 1.21$ & $7.85 \pm 1.35$ & $7.48 \pm 1.35$ & $7.95 \pm 1.35$ & 0.979 \\
\hline Albumin, g/dL & $2.86 \pm 0.19$ & $2.93 \pm 0.21$ & $2.75 \pm 0.21$ & $2.88 \pm 0.21$ & 0.943 \\
\hline Glubulin, g/dL & $4.88 \pm 1.28$ & $4.82 \pm 1.43$ & $4.73 \pm 1.43$ & $5.07 \pm 1.43$ & 0.972 \\
\hline $\mathrm{A} / \mathrm{G}$ ratio & $0.59 \pm 10.20$ & $0.61 \pm 10.24$ & $0.58 \pm 10.24$ & $0.57 \pm 10.24$ & 0.889 \\
\hline Urea, mg/dL & $54.68^{a} \pm 3.08$ & $51.67^{\mathrm{ab}} \pm 3.08$ & $47.73^{\mathrm{b}} \pm 3.08$ & $42.59^{c} \pm 2.76$ & 0.048 \\
\hline Creatinin, $\mathrm{mg} / \mathrm{dL}$ & $0.55 \pm 0.02$ & $0.56 \pm 0.08$ & $0.57 \pm 0.13$ & $0.54 \pm 0.08$ & 0.882 \\
\hline
\end{tabular}

\section{CONCLUSION}

Results of this study indicated that the inclusion of dried Acacia saligna leaves (ALH) up to $60 \%$ of dietary roughage for ewes during late pregnancy stage have a positive impact on their performance and lambs birth weight. Therefore, Acacia saligna (Labill.) H.L. Wendl. forage is an alternative feed supply for sheep during dry periods.

\section{REFERENCES}

Abd El-Aziz, M.M. (1983). A Study on the Biological Efficiency of Meat Production in Barki Sheep.M. Sc. Thesis, Faculty of Agriculture (Moshtohor), Zagazig University, Egypt.

Abdulrazak, S. A., T. Fujihara, J. K. Ondiek, and E. R. Ørskov (2000). Nutritive evaluation of some Acacia tree leavesfrom Kenya. Anim. Feed Sci. Tech., 85: 89-98

Abou El Nasr, H.M., H.M. Kandil, D.M. El Kerdawy, A. Dawlat, H.S. Khamis and H.S. El Shaer (1996). Value of processed saltbush and Acacia shrubs as sheep fodders under the arid conditions of Egypt.Small Rum. Res. 24 (1), 15-20. 
A.O.A.C. (1995). Official Methods of Analysis (15 ${ }^{\text {th }}$ ED.). Association Official Analytical Chemists. Washington, Virginal 1, USA.

Ahn, J.H., B.M. Robertson, R. Elliot and R.C. Gutteridge (1989). Quality assessment of tropical browse legumes: tannin content and protein degradation. Anim. Feed Sci. Technol. 27, 147-156.

Aganga, A.A., C.M. Tsopito, and T. Adogla-Bessa (1998). Feed potential of Acacia species to ruminants in Botswana. Arch. Zootec. 47: 659-668.

Amira, C., G. Louisa, B. Lyas,M. Samir, L. Mohamed, A. Morère, Le Paven Marie-Christine and B. Hacène (2014). Effects of secondary compounds from cactus and acacias trees on rumen microbial profile changes performed by Real- Time PCR. International Journal of Advanced Research, Volume 2, Issue 2, 660-671.

Barry, T.N., T.R. Manley and S.J. Duncan (1986). The role of condensed tannins in the nutritional value of Lotus pedunculatus for sheep. 4. Sites of carbohydrate and protein digestion as influence by dietary reactive tannin concentration. Brit J Nutr 55, 123-137.

Bengaly, K., S. Mhlongo, and I.V. Nsahlai (2007). The effect of wattle tannin on intake, digestibility, nitrogen retention and growth performance of goats in South Africa. Livest. Res. Rural Dev. 19 (4).

Ben Salem, H.M. and A. Nefzaoui (1993). Effect of increasing level of Acacia cyanophylla Lindi. On intake, digestibility and ruminal digestion on sheep fed straw-based diets. $7^{\text {th }}$ Meeting of the FAO European Sub-network on Mediterranean Pastures and Fodder Crops, Management of Mediterranean Shrublands and Related Forage Resources, 21-23 April 1993.Crete, Greece, pp: 118-121.

Ben Salem, H., A. Nefzaoui, L. Ben Salem and J.L. Tisserand (1997). Effect of Acacia cyanophylla Lindl. Foliage supply on intake and digestion by sheep fed lucerne hay-based diets. Anim Feed Sci. Technol. 68, 101-113.

Ben Salem, H., A. Nefzaoui, and L. Ben Salem (1998). Intake, digestibility, urinary excretion of purine derivatives and growth by sheep given fresh, air-dried or polyethylene glycol-treated foliage of Acacia cynophylla land. Anim. Feed Sci. Technol. 78, 297-311.

Carulla J, C. Lascano and T. Klopfenstein (2001). Reduction of tannin level in a tropical legume (Desmodiumovalifolium) with polyethylene glycol (PEG): effects on intake and $\mathrm{N}$ balance, digestion and absorption by sheep. ArchivosLatinoamericanos de Produccion Animal 9, 17-24.

Carulla, J.E., M. Kreuzer, A. Machmuller and H.D. Hess (2005). Supplementation of Acacia mearnsii tannins decreases methanogenesis and urinary nitrogen in forage-fed sheep. Aust. J. Agric. Res. 56, 961-970.

Duncan, D.B. (1955). Multiple ranges and multiple F-test. Biometrics. 11: 1 - 42.

El-Lakany, M.H., S. Mahmoud and A. Bishay, (1991). Agroforestry as a desert farming system, biomass production and feeding quality of Acacia saligna. Proceedings of the $2^{\text {nd }}$ International Development Conference, (IDC'91), Cairo, Egypt, pp: 423-433.

Farid, M.F.A., H.S. Khamis, E.Y.A. Eid and A. Helal (2005a). Feeding management and the performance of sheep in southern Sinai. 2. Reproduction and production performance of the ewe. Journal of Agricultural Sciences, Mansoura University, 30 (12): 7457 - 7476.

Farid, M.F.A. H.S. Khamis, E.Y.A. Eid, R.A. Ahlam and A. Helal (2005b). Feeding Management and the Performance of Sheep in Southern Sinai: 3. The Lambs Pre- and Post-Weaning. J. Agric. Sci., Mansoura Univ., 30 (12): 7477 - 7494.

Frutos, P., M. Raso, G. Hervas, A.R. Mantecon, V. Perez and F.J. Giraldez (2004). Is there any detrimental effect when a chestnut hydrolyzable tannins extract is included in the diet of finishing lambs.Anim Res. 56, 127-136.

Garcia, J., R. Carabaño and J.C. deBles(1999). Effect of fiber source on cell wall digestibility and rate of passage in rabbits. J. Anim. Sci. 77: 898-905. 


\section{Younan et al.}

Hassan, A.A., S.H. Abu Hafsa, M.H. Yacout, M.S. Khalel, M.A.R. Ibrahim and D. Mocuta (2015).Effect of feeding some forage shrubs on goat's performance and rumen fermentation in dry season. Egyptian Journal of Sheep \& Goat Sciences, Proceedings Book of the 5th International Scientific Conference on Small Ruminant Production, Sharm El Sheikh-Egypt, P: 21-36, 2015

Hess, H.D., F.L. Valencia, L.M. Monsalve, G.E. Lascano and M. Kreuzer (2004). Effects of tannins in Calliandracalothyrsus and supplemental molasses on ruminal fermentation in vitro. Journal of Animal and Feed Sciences, 13(Suppl. 1), 96-98.

Kaitho, R.J., N.N. Umunna, I.V. Nahai, S. Tamminga, J.V. Bruchem andJ. Hason ,(1996). Palatability of wilted and dried multipurpose tree species fed to sheep and goats. Anim. Feed Sci. Technol. 65, 151163.

Kearl, L.C. (1982). Nutrient Requirements of Ruminants in Developing Countries. International Feedstuffs Institute (IFI), Utah State University, Logan.

Krebs, G.L., D.M. Howard and K. Dods (2007). Feeding Acacia saligna to sheep and goats with or without the addition of urea or polyethylene glycol. Asian Australasian Journal of Animal Sciences 20:1551-1556.

Kumar, R. and M. Singh (1984). Tannins: their adverse role in ruminant nutrition. J. Agric. Food Chem. $32,447-453$.

Maamouri, O., N. Atti, K. Kraiem, M. Mahouachi (2011). Effect of concentrate and Acacia cyanophylla foliage supplementation on nitrogen balance and milk production of grazing ewes.Journal of Livestock Science. 139 (3): 264-270.

Mahipala, M.B., G.L. Krebs, P. McCafferty, and L.H. Gunaratne (2009). Chemical composition, biological effects of tannin and in vitro nutritive value of selected browse species grown in the West Australian Mediterranean environment. Animal Feed Science and Technology 153:203-215.

Makkar, H.P.S. (2003). Quantification of Tannins in Tree and Shrub Foliage. Kluwer Academic Publisher, Dordrecht, Boston, London,102 p.

McAllister, T.A., T. Martinez, H.D. Bae, A.D. Muir, L.J. Yanke and G.A. Jones

(2005). Characterisation of condensed tannins purified from legume forages: chromophore production, protein precipitation and inhibitory effects on cellulose digestion. J. Chem. Ecol. 31, 2049-2068.

Meneses R. R., Y.V. Olivares, M.S. Martinoli and H. P. Flores (2012). Effect of feeding Acacia saligna on goats stabled during late pregnancy and lactation. Chilean Journal of Agriculture Research, 72 (4): 550-555.

Mlambo, V., F.L. Mould, J.L.N. Sikosana, T. Smith, E. Owen and I. Mueller-Harvey (2008). Chemical composition and in vitro fermentation of tannin-rich tree fruits. Anim. Feed Sci. Technol. 140: 402417.

Mohammed, Mon M.I. (1999). Biological Efficiency of Meat Production from Sheep and Goats. M. SC. Thesis, Faculty of Agriculture, Cairo University, Egypt.

Monteils, V., S. Jurjanz, G. Blanchart and F. Laurent (2003). Effects of crude protein and energy contents of diet on nitrogen distribution between milk, urine and feces by dairy cows. Renc. Rech. Ruminants $10,393$.

Moujahed, N., H. Ben Salem, and C. Kayouli (2005). Effects of frequency of polyethylene glycol and protein supplementation on intake and digestion of Acacia cyanophylla LindI. Foliage fed to sheep and goats. Small Ruminant Res., 56: 65-73. 
Mousa, M.R.M. and M.M. Shetaewi (2002). Milk yield and growth rate as influenced by feeding olive pulp and Acacia shrubs for Awassi sheep under semi-arid conditions. Annales Agric. Sci. Moshtohor, 40: $843-856$.

N.R.C. (1985). Nutrient Requirements of Sheep. $6^{\text {th }}$ Ed., National Academy Press, Washington D.C.

O'Donovan, L., J.D. Brooker (2001). Effect of hydrolysable and condensed tannins on growth, morphology and metabolism of Streptococcus gallolyticus (S. caprinus) and Streptococcus bovis. Microbiol 147: 1025-1033.

Reed, J.D. (1995). Nutritional toxicology of tannins and related polyphenols in forage legumes. J. Anim. Sci., 73: 1516-1528.

Reed, J.D., H. Solter and A. Woodward (1990). Fodder trees and straw diets for sheep: Intake, growth, digestibility and the effects of phenolics on nitrogen utilization. Anim. Feed Sci. Technol., 30: 39-50.

Shawket, Safinaz M. and M.H. Ahmed (2001). The influence of the level of energy supplementation on the utilization of saltbush (Atriplexnummularia) by camels. Egypt. J. Nutr. And Feeds, 4 (Special Issue) 557.

Shawket, Safinaz M., K.M. Yousf and M.H. Ahmed (2010). Comparative evaluation of Egyptian clover and Atriplex Halimus diets for growth and milk production in camel. Animal Science Report, Jannuary. Volume 4, Issue: 1.

S.P.S.S. (1999).“'Statistical Package for Social Science "Release 11, SPSS INC, Chicago. USA.

Tamira,B.and G. Asefab(2009). Effects of different forms of Acacia salignaleaves inclusion on feed intake, digestibility and body weight gain in lambs fed grass hay basal diet, Animal Feed Science and Technology 153: 39- 47.

Van Thanh, D.T., N.T. Mui and I. Ledin (2005). Tropical foliages: Effect of presentation method and species on intake by goats. Anim. Feed Sci. Technol., 118: 1-17.

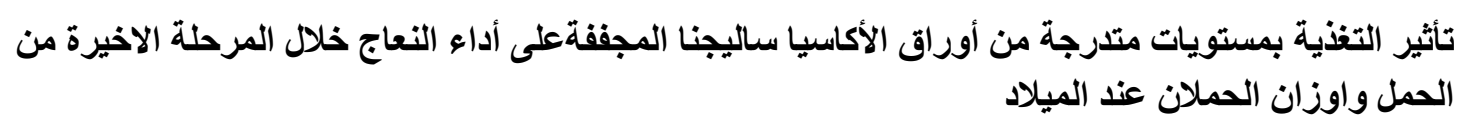

بشرى رشدي يونان1 و حمدي محم خطاب² سافيناز محم شوكت و عادل محم عبدالواحد و أحمد ممدوح منصور2 قسم تغذية الحيوان، مركز بحوث الصحراء ـ مصر

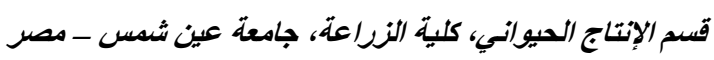

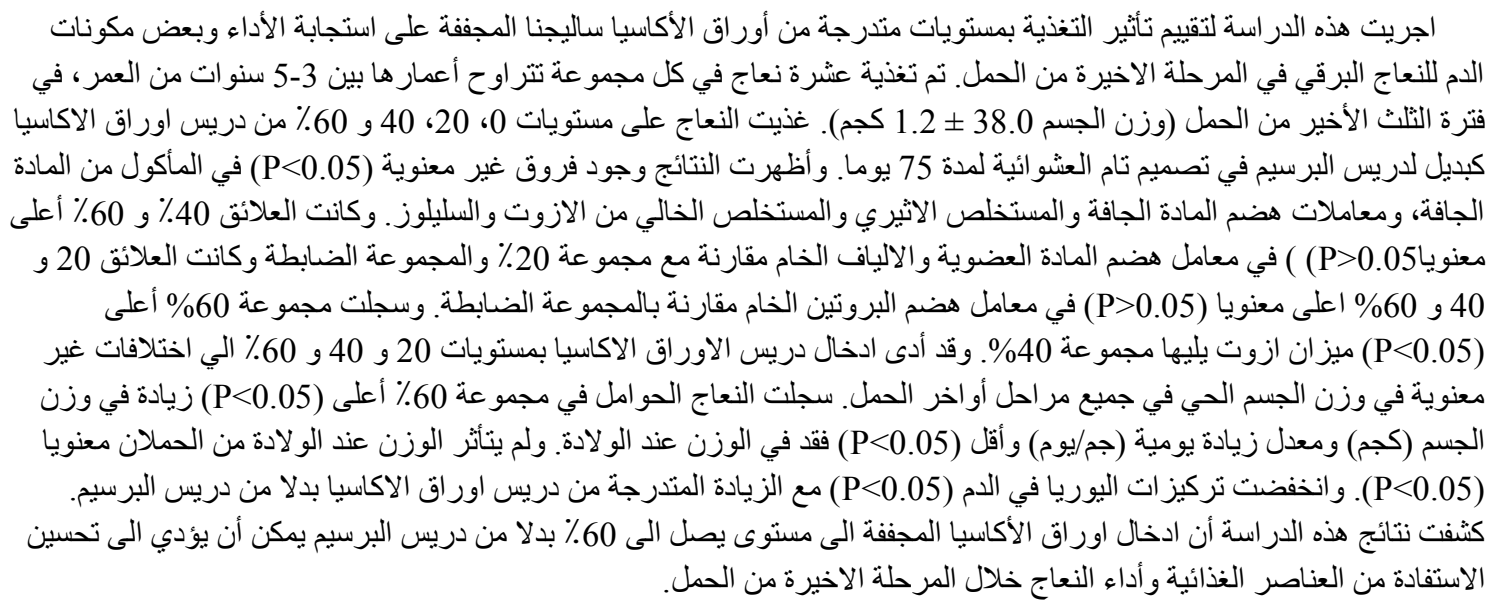

